\title{
Additional data on post-Paleozoic sea-lilies (Crinoidea, Echinodermata) from the Outer Carpathians of the Czech Republic and Poland
}

\author{
Mariusz A. SALAMON ${ }^{1,2}$ \\ Miroslav BuBÍk ${ }^{3}$ \\ Bruno FerRé 4 \\ Andrzej SzYDko 5 \\ Piotr Nescieruk ${ }^{5}$ \\ Bartosz J. PŁaChNo ${ }^{6}$ \\ Tomasz BRACHANIEC ${ }^{1}$

\section{Karolina PAszCZA ${ }^{1}$}

\begin{abstract}
Jurassic (Tithonian) and Lower Cretaceous (Berriasian/Valanginian-Hauterivian) strata of the Vendryně and Cieszyn Limestones formations in the Czech Republic and Poland are locally rich in crinoid remains, consisting of whole cups, isolated cup elements, brachial plates, columnals and pluricolumnals, cirrals, and holdfasts. They are assigned to isocrinids (Isocrinida: Isocrinus cf. amblyscalaris, Isocrinida indet.), cyrtocrinids (Cyrtocrinida: Eugeniacrinites sp., Phyllocrinus sp., Gammarocrinites sp., Hemicrinus tithonicus, Plicatocrinus hexagonus, Cyrtocrinida indet.), millericrinids (Millericrinida: Millericrinida indet.), and thiolliericrinids (Comatulida, Thiolliericrinidae: Thiolliericrinidae gen. et sp. Indet.). Late Cretaceous (Maastrichtian) and Paleogene (Paleocene-Oligocene) crinoids from the Subsilesian Unit are recorded as individual remains belonging to: Isocrinida indet., Cyrtocrinida indet., bourgueticrinids (Comatulida, Bourgueticrinina: Bourgueticrinina fam. et gen. indet.) and roveacrinids (Roveacrinida, Roveacrinidae gen. et sp. indet.). Roveacrinids were retrieved only from Maastrichtian samples. Despite the conclusions previously presented that isocrinids of the Outer Flysch Carpathians dominated around the Jurassic-Cretaceous boundary due to the very shallow sedimentary environment of these strata, we can now conclude that they were common and associated with cyrtocrinids in all types of environments. It is also worth mentioning that cyrtocrinids and isocrinids occur in Paleogene sediments that were deposited in extremely shallow environments. On the other hand, many literature data suggested that Cretaceous (by mid-Cretaceous) isocrinids migrated to deep-water areas, as a response to an increase in the number of predators during the so-called Mesozoic marine revolution.
\end{abstract}

\footnotetext{
${ }^{1}$ University of Silesia in Katowice, Faculty of Natural Sciences, Institute of Earth Sciences, Bedzińska Street 60, 41 200 Sosnowiec (Poland)

2 paleo.crinoids@poczta.fm

${ }^{3}$ Czech Geological Survey, Leitnerova Street 22, 65869 Brno (Czech Republic)

${ }^{4} 2$ rue Guy de Maupassant, F-76800 Saint-Étienne-du-Rouvray (France)

${ }^{5}$ Polish Geological Institute-National Research Institute, Carpathian Branch in Cracow, Skrzatów Street 1, $31-560$ Cracow (Poland)

${ }^{6}$ Jagiellonian University in Kraków, Faculty of Biology, Institute of Botany, Gronostajowa Street 9, 30-387 Cracow (Poland)
}

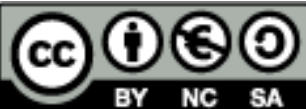

Published online in final form (pdf) on October 14, 2020

[Editor: Bruno GRANIER; language editor: Stephen CAREY] 


\section{Key-words:}

- Western Carpathians;

- Silesian Unit;

- Subsilesian Unit.

- Jurassic;

- Cretaceous:

- Paleogene;

- Crinoidea

- Cyrtocrinids;

- taxonomy;

- Czech Republic;

- Poland

Citation: Salamon M. A., Bubík M., Ferré B., SzydŁo A., Nescieruk P., PŁachno B.J., Brachaniec T. \& PASzCZA K. (2020).- Additional data on post-Paleozoic sea-lilies (Crinoidea, Echinodermata) from the Outer Carpathians of the Czech Republic and Poland.- Carnets Geol., Madrid, vol. 20, no. 15, p. 283299.

Résumé : Données complémentaires sur les lys de mer post-paléozoïques (crinoïdes ; Crinoidea, Echinodermata) des Carpathes externes de la République tchèque et de Pologne.- Les dépôts jurassiques (Tithonien) et crétacés inférieurs (Berriasien/Valanginien-Hauterivien) des formations de Vendryně et des Calcaires de Cieszyn de la République tchèque et de Pologne sont localement riches en restes crinoïdiques, représentés par des thèques entières, éléments isolés de thèque, pièces brachiales, columnales et pluri-columnales, de cirres et de crampons. Ils sont rapportés respectivement aux isocrinides (Isocrinida : Isocrinus cf. amblyscalaris, Isocrinida indet.), cyrtocrinides (Cyrtocrinida : Eugeniacrinites sp., Phyllocrinus sp., Gammarocrinites sp., Hemicrinus tithonicus, Plicatocrinus hexagonus, Cyrtocrinida indet.), millericrinides (Millericrinida : Millericrinida indet.) et aux thiolliericrinides (Comatulida, Thiolliericrinidae : Thiolliericrinidae gen. et sp. indet.). Ces crinoïdes du Crétacé supérieur (Maastrichtien) et du Paléogène (Paléocène-Oligocène) sont représentés par des restes isolés appartenant aux : Isocrinida indet., Cyrtocrinida indet., bourgueticrinides (Comatulida, Bourgueticrinina : Bourgueticrinina fam. et gen. indet.) et aux rovéacrinides (Roveacrinida, Roveacrinidae gen. et $\mathrm{sp}$. indet.). Les rovéacrinides ont été récupérés uniquement dans les échantillons du Maastrichtien. Malgré les conclusions présentées préalablement que les isocrinides des Carpathes du Flysch externe dominaient aux alentours de la limite Jurassique-Crétacé en raison de l'environnement sédimentaire beaucoup moins profond de ces dépôts, nous pouvons maintenant conclure qu'ils furent communs et associés aux cyrtocrinides dans tous les types d'environnement. Il est également utile de préciser que les cyrtocrinides et les isocrinides sont présents dans les sediments paléogènes qui furent déposés dans les environnements extrêmement peu profonds. De nombreuses données suggèrent que les isocrinides crétacés (depuis le Crétacé moyen) ont migré dans les zones d'eaux profondes en réponse à l'accroisssement du nombre de prédateurs lors de la soi-disant révolution marine mésozoïque.

\section{Mots-clefs :}

- Carpathes occidentales ;

- Unité silésienne ;

- Unité sous-silésienne ;

- Jurassique ;

- Crétacé ;

- Paléogène ;

- Crinoidea ;

- taxonomie ;

- République tchèque ;

- Pologne

\section{Introduction}

HOHENEGgER (1861) was the first to mention crinoid remains from the Outer Flysch Carpathians, namely Pentacrinites annulatus RöMER from the Vendryně Formation and the upper member of the Cieszyn Limestone Formation. RoGALA (1909) and KoKOSZYŃSKA (1949) claimed that remains of Pentacrinus sp. (=Isocrinus?) and Pentacrinus neocomiensis (DESOR) (=Isocrinus? neocomiensis) are common in the Lower Cretaceous of the Outer Carpathians. However, such statements and taxonomic assignments raised our doubts and needed to be verified. Later, unspecified echinoderms were also mentioned from both the Czech and Polish sectors of the Outer Carpathians (Cieszyn Beds) (e.g., WAśkowsKA-
Oliwa et al., 2008). Crinoids from the Polish sector of the Outer Carpathians (Cieszyn Limestone Formation) were the sole topic of SALAMON et al. (2020). These latter authors stated that the echinoderms are absent from the Vendryně and Hradiště formations (Tithonian and Berriasian/Valanginian-Hauterivian respectively). They added that Isocrinus cf. amblyscalaris (THURMANN) and Isocrinida indet. both occur in the Vendryne Formation (Tithonian), whereas crinoids are more diversified in the Cieszyn Limestone Formation (Berriasian) and are represented by isocrinids (Isocrinida) and cyrtocrinids (Cyrtocrinida) belonging to the following taxa: Isocrinus? annulatus (ROEMER), Balanocrinus subteres (MüNSTER), B. cf. smithi HESS \& GALE, and Hemicrinus sp. 


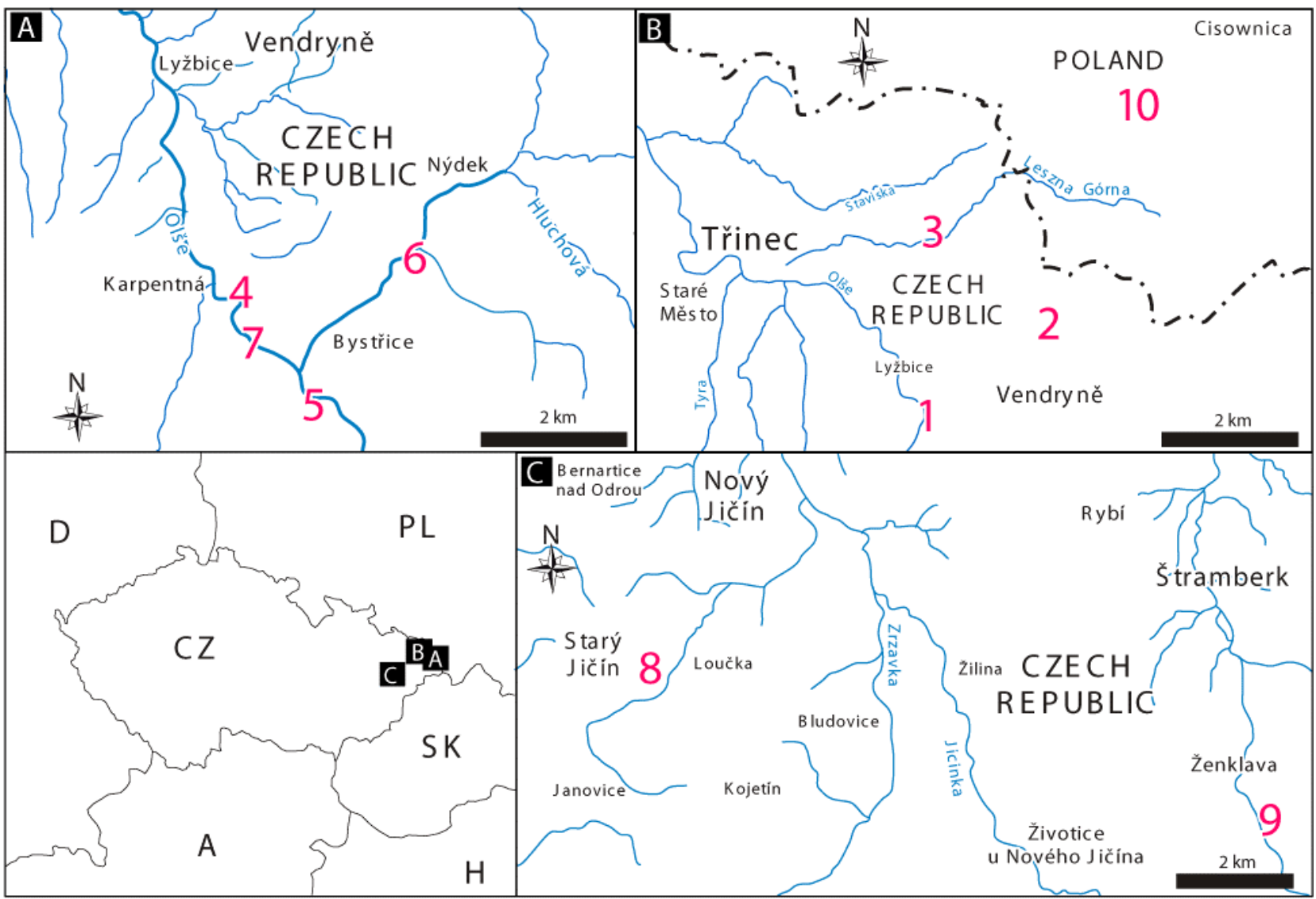

Figure 1: Map of Central Europe with studied sections in the Czech Republic and Poland: 1 - Olza river gorge in Vendryně, 2 - Wopienka Quarry in Vendryně, 3 - Dolní Líštná Quarry, 4 - Bystřice nad Olší, 5 - Jatný, 6 - Hluchová, 7 Zaolší, 8 - Starý Jičín, 9 - Ženklava, 10 - Leszna Górna Quarry.

Figure 1 : Carte géographique d'Europe centrale avec localisation des sections étudiées en République tchèque et en Pologne: 1 - coupe de la rivière Olza à Vendryně, 2 - carrière Wopienka à Vendryně, 3 - carrière de Dolní Líštná, 4 Bystřice nad Olší, 5 - Jatný, 6 - Hluchová, 7 - Zaolší, 8 - Starý Jičín, 9 - Ženklava, 10 - carrière de Leszna Górna.

The Outer Carpathians extend to Ukraine. KLIKUSHIN (1992) recorded the following Jurassic taxa from the Ukrainian Carpathians: Chladocrinus oceani (ORBIGNY) from the Pliensbachian, and Balanocrinus subteres from the Callovian and Tithonian strata. However, in the same paper, KLIKUSHIN (1992, p. 151, first two lines) also described Margocrinus zitteli, now regarded as $B$. subteres, as a new species. According to KRAJEWSKI et al. (2020), only two isocrinid taxa (Balanocrinus sp., and Isocrinina fam. et subfam. indet.) occur in the Jurassic sediments of the Ukrainian Outer Carpathians. They added that, because of the limited size of the samples and/or the type of maceration, no complete isocrinid element was retrieved from any Cretaceous sample. Therefore no crinoid remains have ever been identified from post-Jurassic sedimentary rocks of Ukraine.

During current investigations of the Tithonian, Berriasian-Valanginian, Maastrichtian and Paleocene-Oligocene, exposures in the Czech Republic were selected for crinoid research (Fig. 1). They yielded reasonably common crinoid ossicles belonging to the isocrinids and cyrtocrinids and rare ossicles of bourgueticrinids, millericrinids, and thiolliericrinids. In Poland, a single locality (Leszna Górna Quarry; Valanginian), not previously in- vestigated (for details see SALAMON et al., 2020), was selected for echinoderm research. In this active quarry, many isocrinids and cyrtocrinids were collected, along with abundant thiolliericrinids and scarce millericrinids. The results of taphonomic, palaeoecological and systematic studies of the crinoid faunas are presented herein.

\section{Geological setting}

The studied sections, including selected deposits of the Silesian and Subsilesian units, were recognised in the Western (MoravianSilesian) Carpathians of the Czech Republic and Poland (ŻYTKO et al., 1989). In this area the Carpathian orogen comprises deep- and shallowwater sediments from the Upper Jurassic to the lower Miocene that underwent complex deformation that terminated during the middle Miocene. Most of them feature deposition by turbidity currents and other gravity flows in very tectonically active basins which were repeatedly divided and unified during both subsidence and uplift. The basins developed in the context of the rise and folding of the Carpathian orogen (OSZCZYPKO, 2006; JANKOWSKI, 2015). The sedimentary complex also includes carbonate and non-carbonate pelagic and hemipelagic sediments 
that filled the basin during periods of low tectonic activity and stable sea level. Some of the sediments, determined as Upper Jurassic-Lower Cretaceous (Silesian unit) and Upper Cretaceous-Paleogene (Subsilesian unit), have previously been examined for crinoids. HoHENEGger (1861) subdivided the oldest strata of the Silesian Unit into the "Unterer Teschenerschiefer" (Lower Cieszyn Shale), "Teschnerkalkstein" (Cieszyn Limestone) and the "Oberer Teschenerschiefer" (Upper Cieszyn Shale). The same author distinguished the "untere-" and "obere Abtheilung" within the Cieszyn Limestone (Lower and Upper Cieszyn Limestone). To avoid the confusion of having several stratigraphic units derived from the same toponym, we follow the revised lithostratigraphy of ELIÁš et al. (2003) in the Czech Outer Carpathians. According to this proposal, the oldest strata of the Silesian Unit are divided into the Vendryně Formation (=Lower Cieszyn Shale; Tithonian), the Cieszyn Limestone Formation (Tithonian-Valanginian) with a lower micritic member and an upper siliciclastic member, and the Hradište Formation including the former Upper Cieszyn Shale (Valanginian-Hauterivian). For mo- re details on the correlation between these deposits see SALAMON et al. (2020), and for the detailed geology of the area which extends from the quarry located in the vicinity of Leszna Górna to the Polish-Czech border see Nescieruk and Wójcik (2004, 2013).

Apart from the oldest sedimentary rocks in the Czech-Polish border area, Upper Cretaceous and Paleogene deposits outcropping in the Czech territory were also investigated (Fig. 2). These mostly hemipelagic, pelitic rocks are divided into several formations: the Frýdek Formation (Turonian-Paleocene), the Frýdlant Formation (Maastrichtian-Eocene) and the Menilite Formation (Oligocene) (BuBIK et al., 2016). The Frýdek and Frýdlant formations were deposited mostly under oxic conditions and locally contain a macrofauna of small fossils. The Menilite Formation was deposited under anoxic/dysoxic conditions and lacks a calcareous benthonic macrofauna. These strata are locally replaced by a pebbly mudstone facies containing a macrofauna redeposited from various sublittoral habitats (molluscs, bryozoans, echinoderms, etc.).

\begin{tabular}{|c|c|c|c|c|c|c|c|}
\hline \begin{tabular}{|l|} 
Tithonian \\
\end{tabular} & 1) Vendrynĕ - Olza & & & & & & \\
\hline Berriasian-Valanginian & 2) Vendryně - Wopienka & X & & & & & \\
\hline Berriasian-Valanginian & 3) Dolní Líštná & $V$ & & & & & \\
\hline Maastrichtian & 4) Bystř̌ice nad Olší & X & & & & X & \\
\hline Eocene/Oligocene & 5) Jatný & $X$ & & & & & X \\
\hline Eocene/Oligocene & 6) Hluchová & & & & & & \\
\hline Eocene/Oligocene & 7) Zaolší & & & & & & X \\
\hline Paleocene & 8) Starý Jičín & X & & & & & X \\
\hline Eocene/Oligocene & 9) Ženklava & & & & & & \\
\hline
\end{tabular}

Figure 2: Lithostratigraphic chart of crinoid-bearing strata of the Silesian and Subsilesian units with indicated position of studied sections (for section identification see Fig. 1).

Figure 2 : Tableau lithostratigraphique des dépôts livrant des crinoïdes des Unités silésienne et sous-silésienne avec localisation des coupes étudiées (pour l'identification des coupes, voir Fig. 1). 


\section{Materials and methods}

The crinoid collection from the Leszna Górna Quarry is housed at the University of Silesia in Katowice, Faculty of Natural Sciences, Institute of Earth Sciences, Poland, and recorded under catalogue number: GIUS 8-3693. The crinoids from the Czech localities (Vendryně and Dolní Líštná) are partly housed in the collections of the Czech Geological Survey in Brno, Czech Republic: CGS MB15 to 40.

Crinoids were retrieved from the following localities (see Figs. 1 - 2):

1. Olza River gorge in Vendryně (49³9'

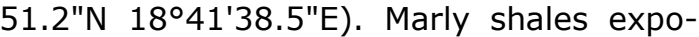
sed in the river gorge are part of the Vendryně Formation. They are early Tithonian in age, based on the macrofauna with Exogyra nana (ŘEHOŘ et al., 1978; VAŠíČEK, 1972). Crinoid elements were obtained during 1979-1980 by washing weathered, easily disintegrating rock from marly paraconglomerate bodies. Marly shales and para-conglomerates are hemipelagites and slump masses deposited in the bathyal zone. Crinoids are very probably reworked from carbonate platforms together with other macrofauna, carbonate ooids, etc.

2. Wopienka Quarry in Vendryně (4940' $\left.34.5^{\prime \prime} \mathrm{N} 18^{\circ} 43^{\prime} 07.3^{\prime \prime} \mathrm{E}\right)$. A few thick banks of detrital limestone formerly exposed in the quarry can be assigned to the upper member of the Cieszyn Limestone Formation. The crinoid remains were collected from weathered surfaces of siliciclastic-limestone banks in 1977. The presumed age of the strata is Berriasian-Valanginian as in the Dolní Líštná quarry. During the 2019 fieldtrip, the quarry wall was no longer accessible, being completely covered by slope debris and vegetation. The detrital limestones were deposited in the same sedimentary setting as identical strata of the Dolní Líštná Quarry.

3. Dolní Líštná Quarry $\left(49^{\circ} 41^{\prime} 17.3^{\prime \prime N} 18^{\circ}\right.$ 41'45.9"E). Thick-bedded marlstones interbedded with marly siltstones and marlstones are assigned to the upper member of the Cieszyn Limestone Formation. The lower part of the quarry wall is upper Berriasian and the upper part, lower Valanginian, based on dinocyst biostratigraphy (Boorová et al., 2003). Numerous isolated crinoid elements were retrieved during field seasons in 1979-1981 by washing rusty weathered residues from crevices in limestone banks. The common occurrence of crinoids was confirmed during summer 2019 by three of us (MB, MAS and TB). The detrital limestones were deposited by turbidity currents in a submarine fan in the bathyal zone. Contained crinoids, oysters, bryozoans, brachiopods, carbonate ooids, etc. are reworked from the carbonate platform.

4. Bystřice nad Olší (49³8'23.9"N 1842' 17.1"E). The Maastrichtian to Selandian strata of the Frýdek Formation are exposed in the large meander of the Olše River (socalled Bouček locality). The section consists of grey marls with slumps and slides. Crinoid ossicles were picked from washed residues of the Maastrichtian strata. The marls with slumps were deposited in upper bathyal depths, and crinoids may either be reworked from the deeper sublittoral or even autochthonous.

5. Jatný $\left(49^{\circ} 37^{\prime} 35.0^{\prime \prime} \mathrm{N} \quad 18^{\circ} 43^{\prime} 06.9^{\prime \prime} \mathrm{E}\right)$. Brown-grey pebbly mudstones and paraconglomerates exposed at Jatný Creek in Bystřice nad Olší can be assigned to the slumped facies of the Menilite Formation (Oligocene). Crinoid ossicles are a part of the reworked shelly macrofauna. The planktonic foraminiferal assemblage is composed of multiple taxa reworked from various Eocene levels and may indicate an Eocene age for the crinoid remains. The pebbly mudstones were deposited in the upper bathyal zone. The macrofauna is reworked from different sublittoral and upper bathyal habitats, so the original habitat of the crinoids is not known.

6. Hluchová (49³8'44.6"N 1844'22.0"E). Oligocene strata similar to those of the Jatný section were exposed in the Hluchová River gorge. Brown-grey pebbly mudstones contain large foraminifers and a shelly macrofauna of diminutive size (bryozoans, molluscs, brachiopods, echinoderm ossicles, etc.). Crinoid remains were picked from washing residues. The fauna may be partly or completely reworked from the Eocene. The outcrops, now covered, are no longer accessible. The sedimentary setting was probably the same as that at Jatny.

7. Zaolší (49³8'07.2"N 1842'22.9"E). Oligocene strata similar to those of the Jatný section are exposed in the left (southern) river bank of the Olše River at Bystrice and Olší. Faunal composition, age and sedimentary setting are nearly the same as those of the Jatný section.

8. Starý Jičín (49³4'39.5"N 1758'10.2"E). Occasional excavation exposed dark-grey calcareous claystones with few turbiditic calcareous sandstones and fine-grained biodetritic conglomerates, up to $160 \mathrm{~cm}$-thick. These strata are part of the Frýdek Formation. Planktonic foraminifers from the claystones indicate a Danian to Selandian age. Crinoid remains were retrieved from washed residues of the disaggregated conglomerate. The hemipelagic claystones 
were deposited at upper or middle bathyal depths. The crinoids and other macrofauna, including bryozoans, bivalves and echinoids, are reworked from the sublittoral zone.

9. Ženklava (49³3'17.0"N 1806'52.1"E). Dark brown-grey pebbly mudstones with calcareous sandstone layers exposed in a small stream can be assigned to the lower Oligocene pebbly mudstone facies of the Menilite Fm. Rare crinoid ossicles were picked up from the washing residues of microfauna. The sedimentary setting was probably the same as that at Jatný.

10. Leszna Górna Quarry $\left(49^{\circ} 42^{\prime} 14.5^{\prime \prime} \mathrm{N} 18^{\circ}\right.$ $\left.44^{\prime} 07.5^{\prime \prime E}\right)$. This active quarry in Poland exposes the upper member of the Cieszyn $\mathrm{Li}$ mestone Formation. Medium- to thick-bedded, coarse-grained detrital limestones, interbedded with black silty shales and marly shales, prevail. The stratigraphy of these strata is complicated by the overthrusting of tectonic slices, each one subdivided internally into blocks by strike-slip faults (e.g., KOPRIANIUK, 2007). The thinning of the limestone banks and the growing proportion of shales in the top of the quarry indicate the transition to the overlying Hradište Formation (upper Valanginian according to its foraminiferal content). Thus the detrital limestones of the Cieszyn Limestone Formation are most probably also Valanginian. The occurrence of a crinoid fauna was confirmed previously. A specimen of Plicatocrinus hexagonus SIEVERTS-DORECK, now lost, was found (BP in 2004) in debris covering the northern wall of the Leszna Górna Quarry. A new collection was made in the quarry (MB, MAS and TB in August 2019), and crinoids were found at the eastern end of the first operating level of the quarry.

Crinoid remains occurring on the surface of slabs were photographed in the field using an iPhone S. In addition, seven carbonate samples, each weighing from 5 to $7 \mathrm{~kg}$, were collected and taken back to the Laboratory of the Institute of Earth Sciences, Faculty of Natural Sciences, University of Silesia, in Katowice. Five samples were selected at random, and a series of thin sections (TS) and polished slabs (PS) were prepared. TS and PS were then investigated and interpreted (BF). The next step consisted in treating the rock samples with GLAUBER's salt (up to five cycles of boiling-thawing). The mixture was then washed using running hot tap water and screened on a sieve column ( $\varnothing 1.0,0.315$ and $0.1 \mathrm{~mm}$ mesh, respectively). Finally all macerated samples were dried at $180^{\circ} \mathrm{C}$. Residues were hand-picked using a microscope. Some specimens were cleaned with hot hydrogen peroxide and then rinsed under running hot tap water. All crinoids recovered from maceration were photographed using a Canon Eos 350D digital camera.

\section{Results}

As a result of our new investigations during 2019, numerous remains consisting of crinoid cups, isolated cup elements, brachial plates, columnals, and pluricolumnals were collected. The following taxa were identified:

- Isocrinus cf. amblyscalaris (THURMANN, in THURMANN \& ÉTALLON), represented by more than 200 isolated columnals and pluricolumnals, and columnals and pluricolumnals visible on PS. I. cf. amblyscalaris was collected in the Leszna Górna Quarry (Valanginian; Poland), Olza River gorge (Tithonian; Czech Republic), the Dolní Lištná Quarry (Berriasian-Valanginian; Czech Republic), and the Wopienka Quarry (Berriasian-Valanginian; Czech Republic).

- Isocrinida indet., represented by more than 300 isolated columnals and pluricolumnals, numerous brachials and cirrals, and columnals, pluricolumnals and brachials visible on PS and in TS. Isocrinida indet. was collected in the Leszna Górna Quarry (Valanginian; Poland), Olza River gorge (Tithonian; Czech Republic), the Dolní Lištná Quarry (Berriasian-Valanginian; Czech Republic), the Wopienka Quarry (Berriasian-Valanginian; Czech Republic), Bystřice nad Olší (Maastrichtian; Czech Republic), Starý Jičín (Paleocene; Czech Republic), and Jatný (Eocene/Oligocene; Czech Republic).

- Eugeniacrinites sp., represented by a single cup collected in the Leszna Górna Quarry (Valanginian; Poland).

- Phyllocrinus sp., represented by two cups from the Leszna Górna Quarry (Valanginian; Poland).

- Gammarocrinites sp., represented by six isolated columnals and seven brachial plates. Gammarocrinites sp. was collected in the Leszna Górna Quarry (Valanginian; Poland).

- Hemicrinus tithonicus PISERA \& DZIK, represented by three cups. $H$. tithonicus was collected in the Leszna Górna Quarry (Valanginian; Poland).

- Cyrtocrinida indet., represented by one partly preserved cup, several isolated cup remains, brachial plates, and columnals visible on PS and in TS. Cyrtocrinida indet. was collected in the Leszna Górna Quarry (Valanginian; Poland), the Dolní Líštná Quarry (Berriasian-Valanginian; Czech Republic), Hluchová, and Ženklava (Eocene/Oligocene; Czech Republic).

- $\quad$ Millericrinida indet., represented by 27 columnals. Millericrinida indet. was collected in the Leszna Górna Quarry (Valanginian; Poland), Olza River gorge (Tithonian; Czech 
Republic), the Dolní Lištná Quarry (Berriasian-Valanginian; Czech Republic), and the Wopienka Quarry (Berriasian-Valanginian; Czech Republic).

- Thiolliericrinidae gen. et sp. indet., represented by 50 columnals. Thiolliericrinidae gen. et sp. indet. was collected in the Leszna Górna Quarry (Valanginian; Poland), Olza River gorge (Tithonian; Czech Republic), the Dolní Líštná Quarry (BerriasianValanginian; Czech Republic), and the Wopienka Quarry (Berriasian-Valanginian; Czech Republic).

- Roveacrinida gen. et sp. indet., represented by a single brachial plate. Roveacrinida was collected in Bystřice nad Olší (Maastrichtian; Czech Republic).

- Bourgueticrinina gen. et sp. indet., represented by three columnals. Bourgueticrinina was collected in Starý Jičín (Paleocene; Czech Republic), Jatný and Zaolší (Eocene/Oligocene; Czech Republic).

\section{Taphonomy}

Only Jurassic and Lower Cretaceous crinoid ossicles (ca. 700 ossicles) were used for taphonomic analyses. Upper Cretaceous-Paleogene individuals were too few. Investigated specimens were scrutinised in search of: 1) epibionts, 2) predation traces, 3) signs of abrasion, chemical alteration of ossicle structure and bioerosion traces, and 4) disarticulation gradient sensu BRETT et al. (1997).

1. Strongly abraded epibionts, most probably serpulids, are detected on the lateral surface of three isocrinid pluricolumnals. They were found only on specimens from the Polish locality (Leszna Górna Quarry). As suggested by SALAMON and GORZELAK (2010), the low frequency of epibionts probably implies that pauses in sedimentation or omission were rare during the deposition of these sediments.

2. Some of the studied ossicles ( $9 \%)$ revealed a large variety of indentations, such as scratches and pits. They are rather shallow and measure $0.3 \mathrm{~mm}$ in width and up to $1.2 \mathrm{~mm}$ in length. All indentations are located on lateral surfaces. They may represent bite marks or barnacle borings; however, it their production during transport cannot be excluded.

3. Eighty percent of Jurassic and $50 \%$ of Cretaceous ossicles have evidence of mechanical abrasion. This is consistent with their transport in gravitational flows. The associated macrofauna consists of thecideid brachiopods, oysters and bryozoans, all indicating shallow-marine, peri-reefal habitats. Some columnals are strongly abraded and rounded, and their articular surfaces are not visible. Similarly, pluricolumnals consisting of several columnals are heavily rounded. According to GORZELAK and SALAMON (2013), such features can arise from transportation over a distance in excess of 100 km (see GORZELAK \& SALAMON, 2013: Fig. 2.c-d). Alternatively, the abrasion of crinoid ossicles may be a side effect of sediment reworking (or transport plus sediment reworking). On the other hand, $20 \%$ of remains display no such signs. Their co-occurrence (abraded ossicles and well-preserved columnals, pluricolumnals, plus cups) indicates that crinoids may represent a mixture of remains from different environments.

Almost $30 \%$ of the Jurassic and $30 \%$ of the Cretaceous ossicles have dissolution traces and their stereom mesh is poorly visible. Additionally, many columnals and pluricolumnals are overgrown by epitaxial calcite. Cretaceous ossicles are brown, yellowbrown and sometimes red from a stain resulting from an iron-oxide coating.

4. As suggested above, crinoid remains represent a mixed assemblage of allochthonous and parautochthonous elements, as supported by the co-occurrence of strongly abraded ossicles, and less abraded, articulated ossicles (e.g., cyrtocrinid cups). The presence of cyrtocrinid cups may be explained by their cups being massive with tightly sutured plates, and, therefore, classified as Taphonomic type III sensu BRETT et al. (1997; see also ZAToń et al., 2008). Bourgueticrinid cups also belong to this type. Isocrinids, millericrinids and thiolliericrinids possessed much more weakly sutured calyx plates and, therefore, are prone to rapid post-mortem disarticulation. They are classified as Taphonomic type II (BRETT et al., 1997), and their most common ossicles are columnals, pluricolumnals and brachials.

\section{Palaeoecology}

While the palaeoecology of bourgueticrinids, millericrinids, and thiolliericrinids is relatively well known (e.g., KLIKUSHIN, 1987; AUSICH et al., 1999, and references therein), the way of life, especially bathymetric preferences, of cyrtocrinids and isocrinids, should be revised. In the recent years, several studies showed that stalked cyrtocrinids commonly lived in both shallow- (SALAMON \& GORZELAK, 2007; ZAMORA et al., 2018; SALAMON, 2019; KRAJEWSKI et al., 2020) and deep-water environments (e.g., ZATOŃ et al., 2008; and literature cited therein). AusICH et al. (1999) stated that cyrtocrinids preferred deeper habitats, typically below $100 \mathrm{~m}$ depth. Extant cyrtocrinids have been documented only at considerable depths (e.g., AusICH et al., 1999; and literature cited therein; DONOVAN \& JAKOBSEN, 2004; for detailed discussion see KrajeWSKI et al., 2020). 
Some authors (e.g., BOTTJER \& JABLONSKI, 1988; OJI, 1996; GoRZELAK et al., 2012) have suggested that isocrinids disappeared from shallow water to take refuge in deep-water settings. OJI (1996) added that isocrinids settled in new and deep-water areas by the Early Jurassic. Earlier OJI (1985) concluded that, during the Mesozoic, a lot of isocrinids migrated to deep zones where they were not subject to predatory attacks. However, he also stated that some isocrinids still preferred shallow seas, e.g., Chariocrinus andreae (DESOR). According to OJI (1985), the last shallow-water representatives of the order Isocrinida are known from the upper Aptian of Japan [Isocrinus hanaii OJI and Isocrinus? neocomiensis (DESOR)]. SALAMON (2007, 2008a, 2008b, 2008c, 2009; see also e.g., JAGT, 1999; HeSS \& GALE, 2010; LACH, 2016; ZamORA et al., 2018; SALAMON et al., 2019) compiled a list of shallow-water Jurassic and Cretaceous (also postAptian) sections containing common isocrinids. AMÉZIANE and Roux (1997) stated that the absence of stalked crinoids from shallow-water settings is a consequence of their functional morphology. They observed that, among Recent stalked crinoids, some forms are also known from relatively shallow-water settings (60 m). Hess (1999) noted that isocrinids are few after the Cretaceous, but we regard this as a sampling bias resulting from palaeogeography (most marine sediments were deposited in shallow waters close to current coastlines). WHITTLE et al. (2018) concluded either that migration of less mobile invertebrates (e.g., isocrinids) into deeper zones was globally asynchronous or that post-Mesozoic isocrinid occurrences from both Antarctica and South America were "retrograde reversions" to Paleozoic-type communities in cool waters. In fact, post-Mesozoic isocrinid are not as rare as claimed, and they are equally common in shallowand deep-water sediments (see data in: e.g. MOORE \& VOKES, 1953; RASMUSSEN, 1972; OJI, 1990; MEYER \& OJI, 1993; DONOVAN, 1995; BAUMILLER \& GAŹDZICKI, 1996; DONOVAN \& VELTKAMP, 2001; SALAMON, 2009; DONOVAN et al., 2015, 2019; SALAMON et al., 2019; WhitTLE et al., 2018; and references therein).

Changes in studied foraminiferal assemblages were strongly influenced by sedimentary conditions. During the late Tithonian, benthonic forms displaying calcite-cemented agglutinating tests (Ataxophragmiidae) and also those secreting calcium-carbonate walls (Involutinidae) became the dominant foraminifers colonizing the shelf area. The Involutinidae especially preferred reef-like environments during the time interval during which the lower part of the Cieszyn Limestone Formation was deposited (Nescieruk \& SzYDŁo, 2001). The following foraminiferal assemblages previously mentioned, also noticed in the Lesznianka stream (Poland), evidence drastic changes in sedimentary regime during the Berriasian. During that time shallow-water sedimentation was replaced by deposition dominated by high-energy gravity flows (including turbidity currents) and resulted in the formation of a carbonate complex with interbedded marly shales (upper part of the Cieszyn Limestones Formation). Hemipelagic sedimentation was also a feature of the Berriasian and predominated during the Valanginian during tectonic quiescence. In that time of decreasing availability of calcium carbonate, sediments were colonised by deep-infaunal detritus- and bacteriafeeders under low-oxygen conditions. They record changes in trophic conditions, leading to the dominance of siliceous agglutinated taxa in foraminiferal assemblages (GEROCH \& KAMIŃSKI, 1995; SZYDŁO, 2004, 2005).

When the crinoid fauna is included in this picture, it is clear that isocrinids, millericrinids and thiolliericrinids occur in Jurassic and Cretaceous deposits. They are accompanied by numerous cyrtocrinids. Though these rocks are deep-water (bathyal), they contain a shallow-water reworked macrofauna including crinoids. KLIKUSHIN (1987) described the largest collection of thiolliericrinids from Crimea to date, where these crinoids lived within the coral reefs. In addition to thiolliericrinids, KLIKUSHIN (1987) often referred to oysters, nerineid gastropods, 'true' (unstalked) comatulids, and echinoids, which all co-occur with them. Similarly, millericrinids occurring in the Upper Jurassic deposits are usually associated with shallow-water environments (e.g., SALAMON \& ZATOŃ, 2005; RADWAŃSKA \& RADWAŃSKI, 2005). On the other hand, deep-water discoveries of millericrinids are known, although most of these are Early Jurassic in age (e.g., HESS, 2006). Late Jurassic and post-Jurassic sedimentation, as indicated above, changed its character from slope hemipelagites and slumps in the Tithonian to turbidites in the Berriasian and Valanginian (with a deepening trend). Also in these much deeper (>200 m) environments, isocrinids and cyrtocrinids, together with millericrinids and thiolliericrinids (Berriasian-Valanginian sections in the Czech Republic: Dolní Líštná Quarry, Wopienka Quarry), were widely distributed. It is also worth mentioning that cyrtocrinids and isocrinids occur in the Paleogene sediments of the Czech Republic (Bystřice nad Olší, Hluchová, Jatný, Starý Jičín, Zaolší, and Ženklava). These deposits are bathyal (upper slope) according to microfossil and lithofacies characteristics. The crinoid remains may be shallowwater but also bathyal. The accompanying fauna is derived from a mix of all these habitats.

We should remember, on one hand, that, in these environments, some invertebrates were redeposited from deeper parts of the sublittoral zone. Therefore, it is possible that some crinoids originally inhabited these zones. On the other hand, the state of preservation of the post-Mesozoic crinoids is quite good, with no signs of abrasion clearly visible on facets, etc. (compare e.g., Fig. 3.J, T-U). It seems unlikely that they underwent vigorous and extended transport. 


\section{Systematics}

The systematics of crinoids follows the scheme proposed by HESS and MESSING (2011).

\section{Order Isocrinida SIEVERTS-DORECK, in MOORE et al., 1952}

Suborder Isocrinina SieVerTS-Doreck, in Ubaghs, 1953

Family Isocrinidae GISLÉN, 1924

\section{Subfamily Isocrininae GISLÉN, 1924}

\section{Genus Isocrinus \\ MeYer, in AgASSIZ, 1836}

Type species: Isocrinites pendulus MEYER, in AgASSIZ, 1836

\section{Isocrinus cf. amblyscalaris (THURMANN, in THURMANN \& ÉTTALON, 1861)}

(Fig. 3.I, L)

1861 ? Pentacrinus amblyscalaris Thurmann, in ThuRMANN \& ÉTTALON, p. 351.

Material. More than 200 isolated columnals and pluricolumnals, and columnals and pluricolumnals visible on PS; catalogue numbers: GIUS 8-3693Ica, CGS MB25.

Description. Columnals are stellate, and medium to large in size. Their diameter is $4.40 \mathrm{~mm}$, and their height varies between 1.45 and 2.60 $\mathrm{mm}$. Crenularium is well developed and consists of a maximum of 18 crenulae per petal. Petal floors are relatively thin, sometimes long. Interradial areas are well developed. Latera ornamented by knobby ridges situated radially or by an interradial knob. Lumen is very small and circular.

Detailed discussion in SALAmon et al. (2020).

Range in Outer Carpathians: Tithonian-Valanginian.

\section{Isocrinidae indet.}

(Fig. 3. $\mathrm{H}, \mathrm{J}-\mathrm{K}$ )

Material. More than 300 isolated columnals and pluricolumnals, numerous brachials, cirrals, columnals, pluricolumnals, and brachials visible on PS and in TS; catalogue numbers: GIUS 83693Iin, CGS MB15, MB16, MB21, MB24, MB26, MB27, MB28, MB32, MB38, MB39.

Description. Columnals are very small to extremely large, with diameter ranging from 0.55 to $10.40 \mathrm{~mm}$. Shape varies from circular to pentagonal or pentalobate, sub-pentagonal and subpentalobate, or stellate. Articular facets are commonly not visible; in some cases only relics of crenulae are visible. It seems that crenulae are thin. Latera is smooth or ornamented by knobby ridges situated radially or by an interradial knob. Lumen is very small and circular. Cirrals are small to medium in size, smooth, and elliptical or circu- lar in section. Brachials are rather small, V- or rarely U-shaped. Proximal facets of primibrachials are muscular. They have large muscle fields; other facets display an embayed synarthry or a cryptosynarthry. Secundibrachials are smooth. They have deeply incised adoral furrows and oblique muscular facets with large muscle fields. Proximal brachials are wide. Distal brachials are higher than wide.

Range in Outer Carpathians: Tithonian-Valanginian, Maastrichtian, Paleocene, Eocene/Oligocene.

\section{Order Cyrtocrinida SIEVERTS-DORECK, 1952}

\section{Suborder Cyrtocrinina} SIEVERTS-DORECK, 1952

\section{Superfamily Eugeniacrinitoidea ROEMER, 1855}

\section{Family Eugeniacrinitidae ROEMER, 1855}

Genus Eugeniacrinites MILLeR, 1821

Type species: Eugeniacrinites quinquangularis MiLLER, 1821

\section{Eugeniacrinites sp.}

(Fig. 3.A)

Material. One cup; catalogue number: GIUS 83693Es.

Description. Cup is smooth, funnel-shaped and slightly pentagonal in outline. Radial articular facets are moderately low and very wide. They have small aboral ligament fossae, deeply excavated inter-articular fossae, and relatively low adoral muscle fossae. Radial articular facets are separated by rather large interradial projections; interradial projections are blunt. Radial cavity is shallow, probably due to matrix infilling. Suture lines are clearly visible. Facet to stem is circular and wide.

Discussion. The generic type species, Eugeniacrinites cariophilites (SCHLOTHEIM), is similar to the cup at hand with its smooth, funnel-shaped and pentagonal in outline cup (cf. HeSs, 1975: Tab. 23, fig. 1; Hess \& Messing, 2011: Fig. 88/1a). However, the stratigraphic range of the type species is restricted to the Middle Oxfordian. There is also some similarity between the specimen at hand and Eugeniacrinites zitteli JAEKEL (blunt interradial projections). This character distinguishes $E$. cariophilites from E. zitteli, as already pointed out by Hess et al. (2011). The latter authors described $E$. zitteli from the Tithonian and Berriasian of eastern Poland. E. zitteli zitteli and E. zitteli moravicus are considered separate species.

For more detailed discussion see Hess et al. (2011).

Range in Outer Carpathians: Valanginian. 


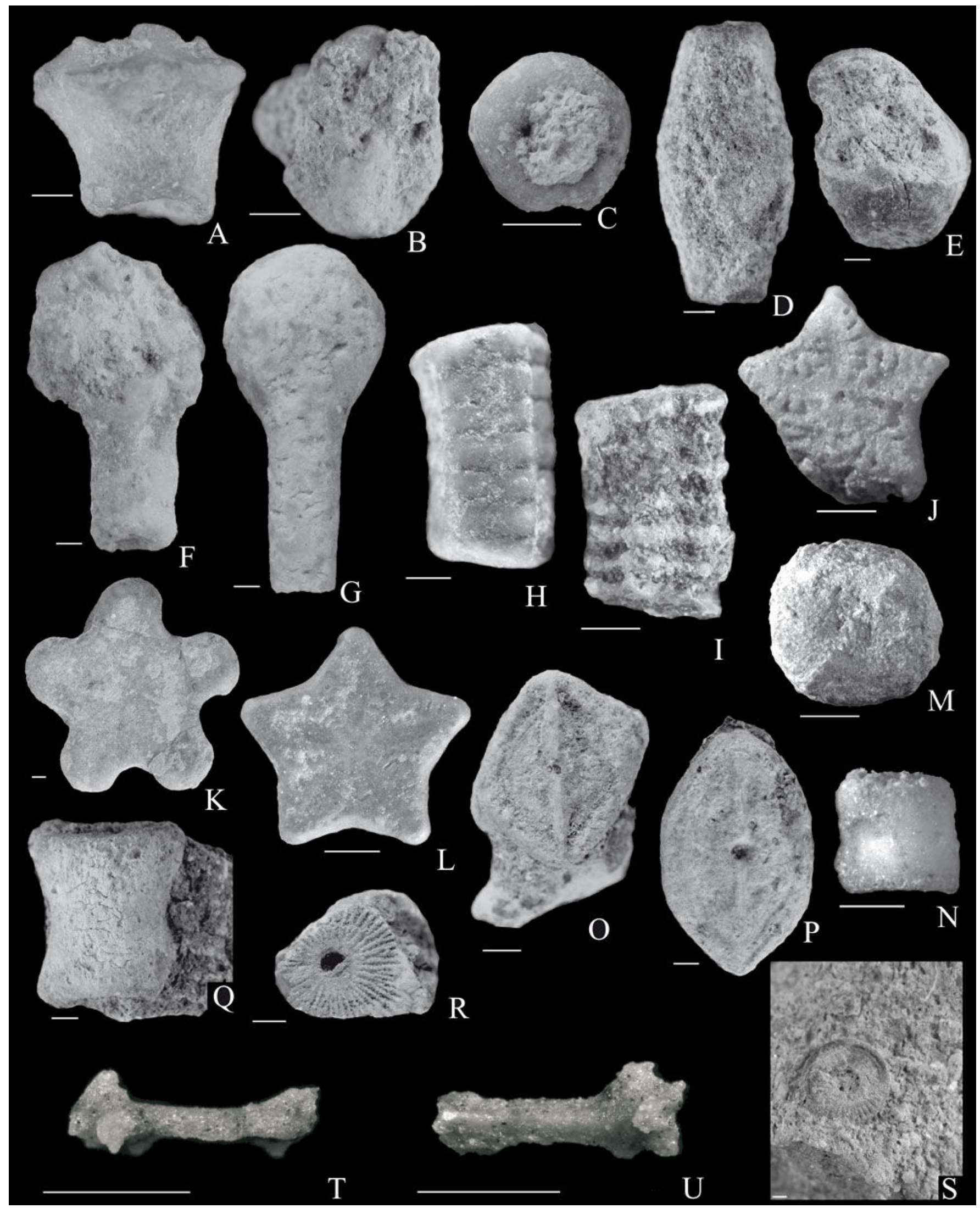


Figure 3: Post-Paleozoic crinoids from Outer Flysch Carpathians of the Czech Republic and Poland. Scale bar equals $1 \mathrm{~mm}$. A. Eugeniacrinites sp., cup, lateral view. Leszna Górna Quarry (Valanginian). GIUS 83693Es. B. Phyllocrinus sp., cup, lateral view. Leszna Górna Quarry (Valanginian). GIUS 8-3693Pm. C-D. Gammarocrinites sp., columnals, articular face (C) and lateral view (D). Leszna Górna Quarry (Valanginian). GIUS 8-3693Gs. E. Cyrtocrinida indet., cup, lateral view. Leszna Górna Quarry (Valanginian). GIUS 83693Ci. F-G. Hemicrinus tithonicus PISERA \& DzIK, cups, adoral (F) and aboral views (G). Leszna Górna Quarry (Valanginian). GIUS 8-3693 Ht. H, J-K. Isocrinidae indet., pluricolumnal, lateral view $(\mathrm{H})$, columnal, articular face (J, K). Leszna Górna Quarry for $\mathrm{H}$ (Valanginian), GIUS 8-3693Iin, Starý J (Paleocene), CGS MB38, and Olza River gorge for K (Berriasian/Valanginian), CGS MB15. I, L. Isocrinus cf. amblyscalaris (THURMANN, in THURMANN \& ÉTTALON), pluricolumnal, lateral view (I) columnal, articular face (L). Leszna Górna Quarry (Valanginian). GIUS 8-3693Ica. M-N. Bourgueticrinina fam. and gen. indet., columnals, articular face (M) and lateral view (N). Starý Jičín (Paleocene). CGS MB37. OQ. Thiolliericrinidae gen. et sp. indet., columnals, articular face $(\mathrm{O}, \mathrm{P})$ and lateral view (Q). Wopienka Quarry for O (Berriasian/Valanginian), CGS MB19, Dolní Líštná Quarry for P, (Berriasian/Valanginian), CGS MB22, and Leszna Górna Quarry for Q (Tithonian/Berriasian), GIUS 8-3693Th. R-S. Millericrinida indet., columnals, articular faces. Leszna Górna Quarry for R (Tithonian/Berriasian), GIUS 8-3693Mi, and Wopienka Quarry for S (Berriasian/Valanginian), CGS MB20. T-U. Roveacrinida indet., brachial. Bystřice nad Olší (Maastrichtian), CGS MB31.

Figure 3 : Crinoïdes post-paléozoïques des Carpathes externes du Flysch de la République tchèque et de Pologne. Barre d'échelle : $1 \mathrm{~mm}$. A. Eugeniacrinites sp. thèque, vue latérale. Carrière de Leszna Górna (Valanginien). GIUS 8-3693Es. B. Phyllocrinus sp., thèque, vue latérale. Carrière de Leszna Górna (Valanginien). GIUS 8-3693Pm. C-D. Gammarocrinites sp., columnales, face articulaire $(C)$ et vue latérale (D). Carrière de Leszna Górna (Valanginien). GIUS 8-3693Gs. E. Cyrtocrinida indet., thèque, vue latérale. Carrière de Leszna Górna (Valanginien). GIUS 8-3693Ci. F-G. Hemicrinus tithonicus PISERA \& DZIK, thèques, vues adorale $(F)$ et aborale (G). Carrière de Leszna Górna (Valanginien). GIUS 8-3693 Ht. H, J-K. Isocrinidae indet., pluricolumnale, vue latérale $(H)$, columnale, face articulaire $(\mathrm{J}, \mathrm{K})$. Carrière de Leszna Górna pour H (Valanginien), GIUS 83693Iin, Starý Jičín (Paléocène), CGS MB38, et talus de la rivière Olza pour $\mathrm{K}$ (Berriasien/Valanginien), CGS MB15. I, L. Isocrinus cf. amblyscalaris (THURMANN, in THURMANN \& ÉTTALON), pluricolumnale, vue latérale (I), columnale, face articulaire (L). Carrière de Leszna Górna (Valanginien). GIUS 8-3693Ica. M-N. Bourgueticrinina fam. et gen. indet., columnales, face articulaire (M) et vue latérale (N). Starý Jičín (Paléocène). CGS MB37. $\mathbf{O}-\mathbf{Q}$. Thiolliericrinidae gen. et $\mathrm{sp}$. indet., columnales, face articulaire $(O, P)$ et vue latérale $(Q)$. Carrière de Wopienka pour O (Berriasien/Valanginien), CGS MB19, carrière de Dolní Líštná pour $P$, (Berriasien/Valanginien), CGS MB22, et carrière de Leszna Górna pour $Q$ (Valanginien), GIUS 8-3693Th. R-S. Millericrinida indet. columnales, faces articulaires. Carrière de Leszna Górna pour R (Valanginien), GIUS 8-3693Mi, et carrière de Wopienka pour S (Berriasien/Valanginien), CGS MB20. T-U. Roveacrinida indet., brachiale. Bystřice nad Olší (Maastrichtien), CGS MB31.
Family Phyllocrinidae JAEKeL, 1907

\section{Genus Phyllocrinus \\ ORBIGNY, 1850, in 1850-1852}

Type species: Phyllocrinus malbosianus ORBIGNY, 1850, in 1850-1852

\section{Phyllocrinus sp.}

(Fig. 3.B)

Material. Two cups; catalogue number: GIUS 8-3693Pm

Description. Cups are small, pentagonal in outline and display very short interradial processes that are triangular in outline. Radial articular facets are low and shallow with a flat triangular surface. Radial cavity is circular, moderately wide and rather shallow. Cups are narrow at lower part, and gradually expanding up to radial facets. Suture lines between radials are clearly visible. Facet to stem is small and pentagonal.

Discussion. There are numerous phyllocrinid taxa in Jurassic and Cretaceous strata worldwide (for review see ZARĘCZNY, 1876; REMEŠ, 1905; ARENDT, 1974; ŽítT, 1978a, 1978b, 1978c; PISERA \& DZIK, 1979; GłUCHOWSKI, 1987; ZATOŃ et al., 2008; Salamon \& GorzelaK, 2010; Hess et al., 2011; ZAMORA et al., 2018). Some opinions suggest there are significant differences in the structure of phyllocrinid taxa (e.g., KoNIECZYŃSKI et al., 2016). On the other hand, MANNi et al. (1992) concluded that Phyllocrinus furcillatus SPENDEN includes closely related and morphologically inseparable forms (e.g., Phyllocrinus belbekensis ARENDT; Phyllocrinus pieninensis GŁUCHOWSKI; Phyllocrinus stellaris ZARĘCZNY) that probably constitute a lineage. We agree, but decided to classify our specimens as Phyllocrinus sp. due to the small number of available individuals.

Range in Outer Carpathians: Valanginian.

Family Sclerocrinidae JAEKEL, 1918

\section{Genus Gammarocrinites QUENSTEDT, 1858}

Type species: Eugeniacrinites compressus GolDFUSS, 1829

\section{Gammarocrinites sp.}

(Fig. 3.C-D)

Material. Six columnals and seven brachial plates; catalogue number: GIUS 8-3693Gs.

Description. Columnals are generally circular, with some barrel-shaped. Facet may be covered by as many as 14 long, thick crenulae. Latera covered by large and circular tubercles, the latter sometimes irregular. Lumen is rounded and moderately large. Secundibrachials are low and joined by muscular or syzygial articulation. Ambulacral grooves are deep and possess large facet for pinnules. 
Discussion. There are many reports mentioning that cyrtocrinid elements covered with granules are classified as Eugeniacrinites, Sclerocrinus or other ( $c f$. ARENDT, 1974; PISERA \& DZIK, 1979; GŁUCHOWSKI, 1987; SALAMON \& GORZELAK, 2010). Here, granulated elements are provisionally assigned to Gammarocrinites. In Gammarocrinites, granules appear to be larger than those of the other taxa mentioned above. Moreover, they cover both columnals and cup elements (e.g., GtUCHOWSKI, 1987: Fig. 14/7, 8; HeSS \& MESSING, 2011: Fig. 90/4).

Range in Outer Carpathians: Valanginian.

\section{Genus Hemicrinus}

ORBIGNY, 1850, in 1850-1852

Type species: Hemicrinus asterianus =Cyrtocrinus granulatus JAEKEL, 1891

\section{Hemicrinus tithonicus PISERA \& DZIK, 1979}

(Fig. 3.F-G)

1979. Hemicrinus tithonicus - PISERA \& DZIK, p. 815816, Fig. 6, Pl. 3, figs. 6-7.

Material. Three cups; catalogue number: GIUS 8-3693Ht.

Description. Cups are sub-pentagonal, low and moderately wide. Stem parts are well differentiated from spoon elements. Spoon elements are smooth. Radial facets are rather wide and equal in size. Radial aboral surface is crescentic and bears wide ligament fossae with small ligament pit. Radial adoral surface is triangular and wider than the aboral one. It bears two small, circular muscular fossae, both separated by a radial groove. Both surfaces are separated by a transverse fulcral ridge. Central cavity is rather shallow. Suture lines are visible. Facet to stem is concave. Stem part is long and circular in outline.

For detailed discussion see PISERA \& DzIK (1979), and MANNi et al. (1992).

Range in Outer Carpathians: Valanginian.

\section{Cyrtocrinida indet.}

\section{(Fig. 3.E)}

Material. One partly preserved cup, several isolated cup remains, brachial plates, and columnals visible on PS and in TS. All elements are more or less abraded; catalogue number: GIUS 83693Ci.

Description. Only the lower part of the cup is preserved. It is slightly circular, with large, circular, rather shallow facet on stem. All radials assigned to Cyrtocrinida indet. are smooth and compact. Their surface is covered by relatively large pustules. Proximal facets are flat and small; distal facets have distinct muscular fields and very narrow aboral ligament area with a pronounced pit. First primibrachials are low. Second primibrachials are compact. Most of the secundibrachials are uniform in size, with convex aboral si- de. All brachials with convex surface are of muscular type. Columnals are stick-like or barrelshaped. Latera is smooth or granulated, and may be straight or convex. Lumen is circular and rather small.

Range in Outer Carpathians: Tithonian-Valanginian, Eocene/Oligocene.

\section{Order Millericrinida SIEVERTS-DORECK, 1952}

\section{Millericrinida indet.}

(Fig. 3.R-S)

Material. 27 columnals; catalogue numbers: GIUS 8-3693Mi, GCS MB17, MB20, MB30.

Description. Columnals are low and circular. Articular facet is covered by thick crenulae that are mainly short. Lumen is circular and large. Latera is straight and smooth.

For detailed discussion see SALAMON et al. (2020).

Range in Outer Carpathians: Tithonian-Valanginian.

Order Comatulida A.H. CLARK, 1908

Suborder Comatulidina A.H. CLARK, 1908

\section{Superfamily Solanocrinitoidea JAEKEL, 1918}

\section{Family Thiolliericrinidae} A.H. CLARK, 1908

Thiolliericrinidae gen. et sp. indet.

(Fig. 3.0-Q)

Material. 50 columnals; catalogue numbers: GIUS 8-3693Th, CGS MB18, MB22, MB23.

Description. Columnals are of varying size, from $1.5 \mathrm{~mm}$-diameter in small, low, discoidal forms to $7 \mathrm{~mm}$-diameter in large, tall types. Columnals are barrel-shaped, sub-cylindrical or hourglass-shaped. Articular facet is circular or ellipsoidal. Fulcral ridge is serrated in some columnals. Marginal ridge is twinned, with twins almost perpendicular to each other on both sides of columnal. Lumen is very small and circular.

Discussion. KLIKUSHIN (1987) strived to attribute isolated columnals to different thiollericrinid cups. He concluded that columnals of Loriolicrinus asper KLIKUSHIN are low, parallel, hourglass-shaped, or oblique. Their latera could be smooth or tubercular. In another place he also stated that the columnals of $L$. laevis KLIKUSHIN may be parallel and not tall. Likewise concerning Umbocrinus umbonatus KLIKUSHIN with its low, parallel or oblique columnals that could be smooth or granulated (for more details see KLIKUSHIN, 1987: p. 633651). However, in our opinion, associating thiolliericrinid cups with isolated columnals is dubious, especially in levels containing cups assigned to different taxa. 
Range in Outer Carpathians: Tithonian-Valanginian.

\section{Suborder Bourgueticrinina SIEVERTS-DORECK, in UBAGHS, 1953}

\section{Bourgueticrinina fam. and gen. indet.}

(Fig. 3.M-N)

Material. Two columnals and one pluricolumnal; catalogue numbers: GIUS 8-3693Th, CGS MB33, MB37.

Description. Columnals are relatively high with elliptical ends constricted medially and have a fulcral ridge divided by a furrow; rhizocrinid pattern is clearly visible. The lateral surface is smooth and concave. The lumen is very small and circular.

Range in Outer Carpathians: Paleocene, Eocene/Oligocene.

\section{Order Roveacrinida \\ SIEVERTS-DORECK, 1952}

\section{Family Roveacrinidae (PECK, 1943) GALE, 2019}

Roveacrinidae gen. et sp. indet.

$$
\text { (Fig. 3.T-U) }
$$

Material. 1 brachial; catalogue number: CGS MB31.

Description. Single brachial is identified as an isolated second primibrachial plate $(\mathrm{IBr} 2)$, quite uniform in size and outer features, most likely belonging to an individual that was disarticulated shortly after death. It is tall, elongate ('pin-like' or stick-like), nearly cylindrical in section and terminated by two slightly swollen, or bulbous, ends. The outer surface appears nearly smooth but displays a feebly pitted random (reticulate?) ornamentation on the plate body and a weak keel running along the radial edge. On their inner side is a continuous, narrow, and faint shallow furrow (feeding groove) with rounded side edges. The abradial extremity is cut obliquely to the plate length and bears a sloping crypto-synarthrial facet to the first secundibrachial. This proximal muscular facet is slightly rimmed. The adradial extremity is bulbous and bears two distal muscular facets to the next distal first secundibrachial. These muscular facets are directed outward with strong relief, marked ligament fossa and axial canal, and pronounced ligament fossae. The muscle fossae display outer narrow processes.

Discussion. All described morphological features recall the subfamily Roveacrininae or an early relative of the subfamily Hessicrininae (see GALE, 2019). Such roveacrinoidal plates usually occur either in quite large number in marker beds or rarely as scattered elements (current transport, bioturbation). The plate at hand suggests some scattering during transport and/or current winnowing. In any event, this is an allochthonous or a parautochthonous element within an otherwise microfaunal assemblage.

Range in Outer Carpathians: Maastrichtian.

\section{Conclusions}

In the Czech sections of the Vendryner and Cieszyn formations (Outer Carpathians) of Tithonian and Berriasian-Valanginian age, remains (cups, isolated cup remains, brachials, columnals, pluricolumnals, and holdfasts), not previously described, of isocrinids, cyrtocrinids, millericrinids, and thiolliericrinids were found. In Maastrichtian sediments isocrinids and roveacrinids were documented. Paleocene to Oligocene strata yielded isocrinids, bourgueticrinids and cyrtocrinids. Isocrinids, cyrtocrinids, millericrinids, and thiolliericrinids were found in the only Polish location where crinoids had not been characterised before. The documented crinoid remains represent a mixed assemblage of allochthonous and parautochthonous elements. Jurassic and Cretaceous forms are equally common in deep- and shallow-water sediments, while cyrtocrinids and isocrinids present in post-Mesozoic strata occur only in extremely shallow environments.

\section{Acknowledgments}

The valuable assistance of Mateusz SYNCERZ during field work is gratefully acknowledged. Reviewers William I. AuSICH, Samuel ZAMORA, and journal Editor-in-Chief, Bruno GRANIER, substantially improved the manuscript. Thanks are also due to the "KOSBUD" Sp. z.o.o. Company that made access to the Leszna Górna Quarry possible. This research was partially supported financially by the Ministry of Science and Higher Education of Poland as part of the statutory activities of the Faculty of Natural Sciences, University of Silesia, in Katowice and Faculty of Biology, JagielIonian University, in Kraków (N18/DBS/000002).

\section{Bibliographic references}

AgAssiz L. (1836).- Prodrome d'une monographie des Radiaires ou Échinodermes.- Mémoires de la Société des Sciences Naturelles de Neuchâtel, vol. 1 (1835), p. 168-199.

AMEZIANE N. \& Roux M. (1997).- Biodiversity and historical biogeography of stalked crinoids (Echinodermata) in the deep sea.- Biodiversity and Conservation, London, vol. 6, p. 15571570.

ARENDT Y.A. (1974).- Sea-lilies Cyrtocrinids.- Trudy Paleontologicheskogo Instituta, Moskow, 250 p. [in Russian].

Ausich W.I., Donovan S.K., Hess H. \& Simms M.J. (1999).- Fossil occurrence. In: Hess H., AusicH W.I., BRetT C.E. \& Simms M.J. (eds.), Fossil crinoids.- Cambridge University Press, p. 41-49.

BAUMilleR T.K. \& GAŹDZicki A. (1996).- New crinoids from the Eocene La Meseta Formation of Seymour Island, Antarctic Peninsula.- Acta Palaeontologica Polonica, Varszawa, vol. 55, p. 
101-116.

BOoROVÁ D., SKUPIEN P. \& VAŠÍČEK Z. (2003).- Biostratigraphical study of the Těšín Limestone in the surroundings of Trrinec (lowermost Cretaceous, Silesian Unit of the Outer Western Carpathians).- Transactions of the VŠB - Technical univerzity Ostrava, Mining and Geological Series, XLIX, Monograph, vol. 8, p. 95-105.

BOTTJER D.J. \& JABLONSKI D. (1988).- Paleoenvironmental patterns in the evolution of postPaleozoic benthic marine invertebrates.Palaios, Lawrence - KS, vol. 3, p. 540-560.

Brett C.E., Moffat H.A. \& TAYLOR W.L. (1997).Echinoderm taphonomy, taphofacies, and lagerstätten. In: MAPLES C.G. \& WATERS J.A. (eds.), Geobiology of echinoderms.- The Paleontological Society Papers 3, New York, p. 147-190.

BubÍK M., Franců J., Gilíková H., OtaVa J. \& ŠvábeNICKÁ L. (2016).- Upper Cretaceous to lower Miocene of the Subsilesian Unit (Western Carpathians, Czech Republic): stratotypes of formations revised.- Geologica Carpathica, Bratislava, vol. 67, p. 239-256.

ClaRk A.H. (1908).- New genera of unstalked crinoids.- Proceedings of the Biological Society of Washington, vol. 21, p. 125-136.

DoNOVAN S.K. (1995).- Isocrinid crinoids from the late Cenozoic of Jamaica.- Atlantic Geology, Wolfville - NS, vol. 30, p. 195-203.

Donovan S.K. \& VeltKamp C.J. (2001).- The Antillean Tertiary crinoid fauna.- Journal of Paleontology, Lawrence - KS, vol. 75, p. 721-731.

Donovan S.K. \& JAKOBSEN S.L. (2004).- An unusual crinoid barnacle association in the type area of the Danian (Paleocene, Denmark).Lethaia, Oslo, vol. 37, p. 407-415.

DONOVAN S.K., HARPER D.A.T. \& PORTELL R.W. (2015).- In deep water: a crinoid-brachiopod association in the upper Oligocene of Antigua, West Indies.- Lethaia, Oslo, vol. 48, p. 291 298.

Donovan S.K., Nielsen S.N., Velez-Juarbe J. \& PorTELL R.W. (2019).- The isocrinine crinoid Isselicrinus ROVERETO from the Paleogene of the Americas.- Swiss Journal of Palaeontology, Basel, vol. 138, p. 317-324.

EliÁŠ M., SKUPIEN P. \& VAŠÍČEK Z. (2003).- A proposal for the modification of the lithostratigraphical division of the lower part of the Silesian Unit in the Czech area (Outer Western Carpathians).- Sborník Vědeckých Prací Vysoké školybáňské - Technické univerzity Ostrava, Řada hornicko-geologická, Monografie, vol. 8, p. 713.

GALE A.S. (2019).- Microcrinoids (Echinodermata, Articulata, Roveacrinida) from the Cenomanian-Santonian chalk of the Anglo-Paris Basin: taxonomy and biostratigraphy.- Revue de Paléobiologie, Genève, vol. 38, p. 397-533.

Geroch S. \& KAMIŃSKI M.A. (1995).- An emendation of some Cretaceous species of "Reophax" (Foraminiferida) from northwest Europe and
Poland. In: KAMIŃSKI M.A., Geroch S. \& GASIŃSKI M.A. (eds.), Proceedings of the Fourth International Workshop on Agglutinated Foraminifera.- GRZYBOWSKI Foundation Special Publication, Kraków, vol. 3, p. 117-122.

GISLÉn T. (1924).- Echinoderm studies.- Zoologisk Bidrag från Uppsala, $330 \mathrm{p}$.

GŁUCHOWSKI E. (1987).- Jurassic and Early Cretaceous articulate Crinoidea from the Pieniny Klippen Belt and the Tatra Mts, Poland.- Studia Geologica Polonica, Varszawa, vol. 94, p. 1-102.

Goldfuss G.A. (1829).- Petrefacta Germaniae. 1. Echinodermata. Arnz and Comp., Düsseldorf, $221 \mathrm{p}$.

GorzelaK P. \& Salamon M.A. (2013).- Experimental tumbling of echinoderms - taphonomic patterns and implications.- Palæogeography, Palæoclimatology, Palæoecology, vol. 386, p. 569-574.

Gorzelak P., Salamon M.A. \& Baumiller T. (2012).Predator-induced macroevolutionary trends in Mesozoic crinoids.- Proceedings of the National Academy of Sciences of the United States of America, Washington - DC, vol. 109, p. 70047007.

Hess H. (1975).- Die fossilen Echinodermen des Schweizer Juras.- Veröffentlichungen aus dem Naturhistorischen Museum Basel, vol. 8, 130 p.

Hess H. (1999).- Tertiary. In: Hess H., AusICH W.I., BRETT C.E. \& Simms M.J. (eds.), Fossil crinoids.- Cambridge University Press, p. 233236.

Hess H. (2006).- Crinoids (Echinodermata) from the Lower Jurassic (upper Pliensbachian) of Arzo, southern Switzerland.- Schweizerische Paläontologische Abhandlungen, Basel, vol. 126, p. 1-144.

Hess H. \& Gale A.S. (2010).- Crinoids from the Shenley Limestone (Albian) of Leighton Buzzard (Bedfordshire, UK).- Journal of Systematic Palaeontology, Cambridge, vol. 8, p. 427-447.

Hess H. \& Messing C.G. (2011).- Treatise on Invertebrate Paleontology, Part T, Echinodermata 2, revised, Crinoidea (Vol. 3).- University of Kansas Paleontological Institute, Lawrence $\mathrm{KS}, 261 \mathrm{p}$.

Hess H., Salamon M.A. \& Gorzelak P. (2011).- Late Jurassic-Early Cretaceous (Tithonian-Berriasian) cyrtocrinids from south-eastern Poland.Neues Jahrbuch für Geologie und Paläontologie Abhandlungen, Stuttgart, vol. 260, p. 119128.

HOHENEGgER L. (1861).- Die geognostischen Verhältnisse der Nordkarpathen in Schlesien und den angrenzenden Theilen von Mähren und Galizien. Erläuterung zu der geognostischen Karte der Nordkarpathen.- Justus Perthes, Gotha, $50 \mathrm{p}$.

JAEKEL O. (1891).- Über Holopocriniden mit besonderer Berücksichtigung der Stramberger Formen.- Zeitschrift der Deutschen geolo- 
gischen Gesellschaft, Berlin, vol. 43, p. 557670.

JAEKEL O. (1907).- Über die Korperform der Holopocriniten.- Neues Jahrbuch für Geologie und Paläontologie Festband, Stuttgart, p. 272-309.

JAEKEL O. (1918).- Phylogenie und System der Pelmatozoen.- Paläontologische Zeitschrift, Heidelberg, vol. 3, p. 1-128.

JAGT J.W.M. (1999).- Late Cretaceous-early Palaeocene echinoderms and the $\mathrm{K} / \mathrm{T}$ boundary in the southeast Netherlands and northeast Belgium - Pt. 2: crinoids.- Scripta Geologica, Leiden, vol. 116, p. 59-255.

JANKOWSKI L. (2015).- A new history of the evolution of the Carpathian orogeny - Controversial point of view.- Instytut Nafty i Gazu - Panstwowy Instytut Badawczy u I., Kraków, vol. 202, p. 1-154.

KLIKUSHIN V.G. (1982).- Taxonomic survey of fossil isocrinids with a list of the species found in the USSR.- Geobios, Villeurbanne, vol. 15, p. 299-325.

KLIKUSHIN V.G. (1987).- Thiolliericrinid crinoids from the Lower Cretaceous of Crimea.- Geobios, Villeurbanne, vol. 20, p. 625-665.

KLIKUSHIN V.G. (1992).- Iskopaemye morskie lilii pentakrinidy i ikh rasprostranenie $v$ SSSR.Leningrad Palaeontological Laboratory, 358 p. [in Russian].

KoKosZYŃSKA B. (1949).- Dolna kreda okolic Tomaszowa Mazowieckiego.- Biuletyn Instytutu Nauk Geologicznych, Varszawa, vol. 113, p. 564. (in Polish)

KonieCZYŃSKI K., Pisera A. \& Fözy I. (2016).- Early Cretaceous cyrtocrinids (Crinoidea) from the Gerecse Mountains, northern Hungary.- Neues Jahrbuch für Geologie und Palaontologie, Abhandlungen, Stuttgart, vol. 279, p. 155166.

KoPRANIUK M. (2007).- Small-scale strike-slip faults and accompanying secondary structures - a case study from the quarry in Leszna Górna, Cieszyn Unit (Outer Carpathians). Przegląd Geologiczny, Varszawa, vol. 55, fasc. 5, p. 395-404

Krajewski M., Ferré B. \& Salamon M.A. (2020).Cyrtocrinids (Cyrtocrinida, Crinoidea) and other associated crinoids from the Jurassic (Kimmeridgian-Tithonian) - Cretaceous (Berriasian-Barremian) of the Carpathian foredeep basement (western Ukraine).- Geobios, Villeurbanne, vol. 60, p. 61-77.

LACH R. (2016).- Late Cretaceous sea lilies (Crinoids; Crinoidea) from the Miechów Trough, southern Poland.- Palaeontographica Abt. A, Stuttgart, vol. 305, p. 9-133.

Manni R., Nicosia U. \& Szabó J. (1992).- Late Jurassic crinoids from the Eperkés-hegy (Bakony Mts., Hungary).- Fragmenta Mineralogica et Palaeontologica, Budapest, vol. 15, p. 115137.

MeYer D.L. \& OJi T. (1993).- Crinoids from Seymour Island, Antarctic Peninsula: Paleobiogeo- graphic and paleoecologic implications.- Journal of Paleontology, Cambridge, vol. 67, p. 250-257.

MiLLER J.S. (1821).- A natural history of the Crinoidea or lily-shaped animals, with observations on the genera Asteria, Euryale, Comatula and Marsupites.- Bryan and Co., Bristol, 150 p.

MOORE R.C. \& VoKes H.E. (1953).- Lower Tertiary crinoids from northwestern Oregon.- Geological Survey Professional Paper, Washington DC, vol. 233-E, p. 113-148.

MoORE R., LALICKER C.G. \& FisCHeR A.G. (1952).Invertebrate Fossils. - McGraw-Hill, New York, $766 \mathrm{p}$.

Nescieruk P. \& SzYdŁo A. (2001).- Record of shallow-water sedimentation in the Silesian Basin in the uppermost Jurassic (Western Outer Carpathians).- Biuletyn Instytutu Geologicznego, Warszawa, vol. 396 , p. 110-111.

Nescieruk P. \& Wójcik A. (2004).- Detailed geological map of Poland in the scale of 1:50,000, sheet Cieszyn (1010) (only in Polish) National Geological Archive.- Polish Geological Institute-National Research Institute, Warszawa.

Nescieruk P. \& Wójcik A. (2013).- Explanations to detailed geological map of Poland in the scale of $1: 50,000$, sheet Cieszyn (1010) (only in Polish) National Geological Archive.- Polish Geological Institute-National Research Institute, Warszawa.

Oji T. (1985).- Early Cretaceous Isocrinus from northeast Japan.- Palaeontology, London, vol. 28 , p. 628-642.

OJi T. (1990).- Miocene Isocrinidae (stalked crinoids) from Japan and their biogeographic implication.- Transactions and Proceedings of the Palaeontological Society of Japan, Tokyo, vol. 157, p. 412-429.

OJI T. (1996).- Is predation intensity reduced with increasing depth? Evidence from the West Atlantic stalked crinoid Endoxocrinus parrae (GeRvaIs) and implications for the Mesozoic Marine Revolution.- Paleobiology, Lawrence - KS, vol. 22, p. 339-351.

OrBigny A. d' (1850-1852).- Prodrome de la paléontologie stratigraphique universelle des animaux mollusques et rayonnés faisant suite au cours élémentaire de paléontologie et de géologie stratigraphique.- Masson, Paris, vol. 3, $1017 \mathrm{p}$.

OsZCZYPKo N. (2006).- Late Jurassic-Miocene evolution of the Outer Carpathian fold-and thrust belt and its foredeep basin (Western Carpathians, Poland).- Geological Quarterly, Warszawa, vol. 50, p. 169-194.

PeCK R.E. (1943).- Lower Cretaceous crinoids from Texas.- Journal of Paleontology, Lawrence - KS, vol. 17, p. 451-475.

PISERA A. \& DZIK J. (1979).- Tithonian crinoids from Rogoźnik (Pieniny Klippen Belt, Poland) and their evolutionary relationships.- Eclogae geologicae Helvetiae, Basel, vol. 72, p. 805- 
849.

QueNSTEDT F.A. (1858).- Der Jura.- Laupp, Tübingen, $842 \mathrm{p}$.

RADWAŃSKA U. \& RADWAŃSKI A. (2005).- Myzostomid and copepod infestation of Jurassic echinoderms: A general approach, some new occurrences, and/or re-interpretation of previous reports.- Acta Geologica Polonica, Warszawa, vol. 55, p. $109-130$.

RASMUSSEN H.W. (1972).- Lower Tertiary Crinoidea, Asteroidea and Ophiuroidea from Northern Europe and Greenland.- Det Kongelige Danske Videnskaberne Selskab Biologiske Skrifter, Copenhag, vol. 19, p. 1-83.

ŘEHOŘ F., ŘEHOŘOVÁ M. \& VAŠíčEK Z. (1978).- Za zkamenělinami Severní Moravy.- Ostravské muzeum, 279 p. [in Czech].

REMEŠ M. (1905).- Nachträge zur Fauna von Stramberg VI. Crinoiden-, Asteriden- und Echinoiden-Reste aus dem Weissen Kalkstein von Stramberg.- Beiträge zur Paläontologie und Geologie Österreich-Ungarns und des Orients, Wien, Band XVIII, p. 59-63.

RoEmer F.C. (1855).- Meso-Lethea; IV. Theil, Oolithen Periode. In: BronN H. G. \& Roemer F.C. (eds.), Lethaea Geognostica oder Abbildung und Beschreibung der für die Gebirgs Formationen bezeichnendsten Versteinerungen.Schweizerbart, Stuttgart, $788 \mathrm{p}$.

RogalA W. (1909).- Przyczynki do górnosenońskiej fauny Karpat.- Kosmos, Kraków, vol. 34, p. 739-748 [in Polish].

SALAMON M.A. (2007).- First record of bourgueticrinid crinoids from the Cenomanian of southern Poland.- Cretaceous Research, vol. 28, p. 495-499.

Salamon M.A. (2008a).- The Callovian (Middle Jurassic) crinoids from northern Lithuania.- $\mathrm{Pa}$ läontologische Zeitschrift, Heidelberg, vol. 82, p. 269-278

SALAMON M.A. (2008b).- Jurassic cyrtocrinids (Cyrtocrinida, Crinoidea) from extra-Carpathian Poland.- Palaeontographica A, Stuttgart, vol. 278, p. 1-23.

Salamon M.A. (2008c).- The Callovian (Middle Jurassic) crinoids from the black clays of the Łuków area, eastern Poland.- Neues Jahrbuch für Paläontologie, Abhandlungen, Stuttgart, vol. 3, p. 97-119.

SALAMON M.A. (2009).- Early Cretaceous (Valanginian) sea lilies (Echinodermata, Crinoidea) from Poland.- Swiss Journal of Geosciences, Basel, vol. 102, p. 77-88.

SALAMON M.A. (2019).- A new prospect in crinoid (Crinoidea, Echinodermata) research: An example from the Lower Jurassic of Montenegro.- Carnets Geol., Madrid, vol. 19, no. 12, p. 211-220.

Salamon M.A., Ferré B., Szydło A., Brachaniec T. \& BuBík M. (2020).- New data on crinoid assemblages from the oldest sedimentary rocks of the Polish Outer Carpathians (Jurassic-Cretaceous).- Annales de Paléontologie,
Paris, vol. 106, no. 1, article 102357, 12 p.

SALAMON M.A. \& GoRzelaK P. (2007).- Evidence of shallow-water cyrtocrinids (Cyrtocrinida, Crinoidea) from the Callovian of Poland.- Neues Jahrbuch für Geologie und Paläontologie, Abhandlungen, Stuttgart, vol. 244, p. 257260.

SALAmON M.A. \& Gorzelak P. (2010).- Cyrtocrinids (Echinodermata, Crinoidea) from Upper Jurassic Štramberk-type limestones in southern Poland.- Palaeontology, London, vol. 53, p. 869885.

Salamon M.A., Lin J.-P., DudA P., Gorzelak P., Ausich W.I. \& OJi T. (2019).- Paleoenvironmental and biostratigraphic implications of echinoderm ossicles trapped within Burmese amber.- Palaios, Lawrence - KS, vol. 34, p. 652-656.

SALAMON M.A. \& ZATOŃ M. (2005).- First record of the Jurassic millericrinid Pomatocrinus mespiliformis (von SCHLOTHEIM, 1820) from Poland.Neues Jahrbuch für Paläontologie, Monatshefte, Stuttgart, vol. 5, p. 301-320.

SiEVERTS-DORECK H. (1952).- In: MOORE R.C., LALICKER C. G. \& FISCHER A.G. (eds.), Invertebrate Fossils.- McGraw-Hill, New York, 766 p.

SzYDŁo A. (2004).- The distribution of agglutinated foraminifera in the Cieszyn Basin, Polish Outer Carpathians).- GRZYBOWSKI Foundation Special Publication, Kraków, vol. 8, p. 461470.

SzYDŁo A. (2005).- Benthic foraminiferal morphogroups and taphonomy of the Cieszyn beds (Tithonian-Neocomian, Polish Outer Carpathians).- Studia Geologica Polonica, Warszawa, vol. 124, p. 199-214.

THURMANN A. (1861).- Lethaea Bruntuntana ou Études paléontologiques et stratigraphiques sur le Jura bernois et en particulier les environs de Porrentruy. Oeuvre posthume terminée et publiée par A. ÉTALLon.- Nouveaux Mémoires de la Société helvétique des Sciences naturelles, Zürich, Band XVIII-XX, 500 p. (LXII Pls. + Pls. A-C).

UBAGHS G. (1953).- Sous-Classe 4. Articulata J.S. Miller. In: Piveteau J. (ed.), Traité de Paléontologie 3.- Masson, Paris, p. 756-765.

VASICEK Z. (1972).- Zpráva o paleontologických výzkumech ve východní částislezské jednotky na Třinecku a o nových paleontologických lokalitách $v$ okolí Ostravice (malm-barrem).Sborník vědeckých prací Vysoké školy báňské v Ostravě. Řada hornicko-geologická, vol. 17, p. 197-207 [in Czech].

WAŚKOWSKA-OliWA A., KROBICKI M., GolonKA J., SŁomka T., ŚlączKa A. \& DOKTOR M. (2008).Stanowiska najstarszych skał osadowych w polskich Karpatach fliszowych jako obiekty geoturystyczne (Sections of the oldest sedimentary rocks in Polish Flysch Carpathians as geotouristic objects). In: KROBICKI M. (ed.), Utwory przełomu jury i kredy w zachodnich Karpatach fliszowych polsko-czeskiego pogra- 
nicza. Kwartalnik AGH.- Geologia, Kraków, Tom 34, Zeszyt 3/1, p. 83-121 [in Polish with English abstract].

Whittle R.J., Hunter A.W., CANTRill D.J. \& McNAMARA K.J. (2018).- Globally discordant Isocrinida (Crinoidea) migration confirms asynchronous Marine Mesozoic Revolution.- Communications Biology, vol. 1, p. 46-55.

Zamora S., Aurell M., Veitch M., Saulsbury J., López-Horgue M.A., Ferratges F.A., Arz J. A. \& BAUMILLER T.K. (2018).- Environmental distribution of post-Palaeozoic crinoids from the Iberian and south-Pyrenean basins, NE Spain.- Acta Palaeontologica Polonica, Warszawa, vol. 63, p. 779-794.

ZARĘCZNY S. (1876).- Dodatek do fauny warstw tytonskich w Rogoźniku i Maruszynie.- Sprawozdanie Komitetu Fizyograficznego Akademii Umiejętności, Kraków, vol. 10, p. 218-231 [in Polish].

Zatoń M., Salamon M.A. \& Kaźmierczak J. (2008).Cyrtocrinids (Crinoidea) and associated stalked crinoids from the Lower/Middle Oxfordian (Upper Jurassic) shelfal deposits of southern
Poland.- Geobios, Villeurbanne, vol. 41, p. 559-569.

ŽítT J. (1978a).- Deformations of Phyllocrinus malbosianus d'ORBIGNy from Štramberk (Czechoslovakia).- Časopis pro mineralogii a geologii, Praha, vol. 23, p. 277-284.

ŽítT J. (1978b).- Phyllocrinus d'Orbigny, 1850 (Crinoidea, Cyrtocrinida) from the Lower Cretaceous of Štramberk (Czechoslovakia).Časopis pro mineralogii a geologii, Praha, vol. 23 , p. 39-58.

ŽítT J. (1978c).- Phyllocrinid microcrinoids (Cyrtocrinida) from the Lower Cretaceous of Štramberk (Czechoslovakia).- Věstník Ústředního ústavu geologického, vol. 53, p. 145-151.

ŻYTKO K., GUCIK S., RYŁKO W., OsZCZYPKO N., ZAJAC R., Garlicka I., NemČok J., Elí́š M., MenČIK E., DVOŘÁK J., STRÁNIK Z., RAKUS M. \& MATĚJOVSKÁ O. (1989).- In: Poprawa D. \& NemČoK J. (eds.), Geological map of the Western Outer Carpathians and their foreland without Quaternary formations, Scale 1:500 000.- Państwowy Instytut Geologiczny, Warszawa. 